\title{
REVITALISASI LEMBAGA PRA PENUNTUTAN GUNA MENYOKONG KEPASTIAN HUKUM DAN KEADILAN DALAM SISTEM PERADILAN PIDANA INDONESIA
}

\author{
(Revitalization of Pre Prosecution Institution to Support \\ Legal Certainty and Justice in The Criminal Justice System in Indonesia) \\ Raja Mohamad Rozi \\ Peneliti Pusat Penelitian dan Pengembangan Kejaksaan Agung RI \\ Jl. Sultan Hasanudin No. 1 Kebayoran Baru \\ Email: rozi.zui.iuris@gmail.com
}

Naskah diterima: 15 Maret 2017; revisi: 30 Maret 2017; disetujui: 17 April 2017

\begin{abstract}
Abstrak
Sejak berlakunya KUHAP terjadi deferensiasi fungsional di dalam sistem peradilan pidana yang berkonsekuensi pada hubungan lembaga kepolisian sebagai pelaksana penyidikan tindak pidana umum dan kejaksaan memiliki tugas di bidang penuntutan. Dari hubungan fungsional tersebut terdapat mekanisme yang dinamakan pra penuntutan melalui media korespondensi. Pentingnya lembaga pra penuntutan tersebut sehingga penting untuk mengkaji apakah terdapat kelemahan pengawasan horizontal jaksa kepada penyidik dan apa argumentasi yuridis eksistensi lembaga pra penuntutan dalam KUHAP, yang kajian tersebut akan dijawab menggunakan metode penelitian normatif dengan analisis deskriptifkualitatif. Hasil pengkajian menunjukan lemahnya pengawasan fungsional penyidikan dapat berdampak pada hilangnya keadilan dan kepastian hukum. Kemudian terhadap perluasan peran jaksa peneliti perkara dalam lembaga pra penuntutan berdasarkan KUHAP akan mewujudkan kesepahaman antara penyidik dengan jaksa peneliti perkara/penuntut umum, guna memperkecil risiko gagalnya penuntutan perkara pidana. Atas berbagai temuan tersebut perlu untuk memperkuat lembaga pra penuntutan dalam KUHAP dan perlu perluasan obyek pra penuntutan sampai ke kegiatan penyelidikan, serta perlunya sanksi terhadap penyimpangan mekanisme pra penuntutan bagi aparatur penegak hukum.
\end{abstract}

Kata Kunci: pra penuntutan, perkara, pidana

\begin{abstract}
Since the Criminal Procedure Code implementation, there are different function in criminal justice system which brings consequences to the cooperation between police institutions as general criminal investigator and general attorney as prosecutor. The pre prosecution mechanism through correspondence exists within this functional cooperation. The importance of pre prosecutorial institutions brings urgency to review whether there is weakness in the prosecutor supervision to the investigator and what juridical argumentation of this pre prosecutorial institution's existence in Criminal Procedure Code which is answered by using normative research method with descriptive-qualitative analysis. The result of this research prove there is weakness of supervision toward criminal investigator that result in the disappearance of justice and legal certainty. In the other hand, the expansion of the cases researcher prosecutor role in pre prosecution institutions under the Criminal Procedure Code will bring harmony between the investigators and the cases researcher prosecutor/general prosecutors, and will minimize the failure risk of the criminal cases. Therefore strengthening the Pre Prosecution institutions in the Criminal Procedure Code is needed and the expansion of Pre prosecution objects to also cover exploratory activities. Last but not least the importance of sanction towards the breach of pre prosecution mechanism by law enforcement officials.
\end{abstract}

Keywords: pre prosecution, cases, criminal 


\section{A. Pendahuluan}

Sebelum berakhirnya HIR (het Herziene Inland Reglement) bahwa kewenangan penyidikan semua tindak pidana adalah jaksa (magistraat), sedangkan kepolisian bertindak sebagai "pembantu jaksa" atau hulp magistraat. Lembaga penyidikan berada penuh di bawah kewenangan dan kekuasaan kejaksaan, sehingga di dalam tubuh kejaksaan ada yang disebut Dinas Reserse Pusat yang dikepalai adalah seorang polisi (d/h R.H.K. Sosrodanukusumo). ${ }^{1}$ Demikian pula, Kejaksaan Agung berada di dalam satu atap bersamasama dengan Mahkamah Agung. Posisi seperti ini mengingatkan kepada posisi hukum (recht positie) jaksa dan Kejaksaan Agung di negeri Belanda yang berlaku sampai sekarang ini. ${ }^{2}$ Dengan kewenangan penyidikan secara penuh di bawah kekuasaan Kejaksaan, maka tidak dikenal lembaga "pra penuntutan". Koordinasi antara penyidik dan penuntut umum bersifat personal dan erat karena ketika mulai dilakukan penyidikan, jaksa dapat terlibat langsung bersama-sama dengan polisi. Keadaan seperti ini serupa dengan penyidikan dan penuntutan yang berlaku di Komisi Pemberantasan Korupsi yakni penyidik dan penuntut umum berada di dalam satu atap (one roof system) saat ini.

Sejak berlakunya KUHAP (Kitab UndangUndang Hukum Acara Pidana) maka hubungan sub sistem peradilan pidana yakni kepolisian, kejaksaan dan pengadilan berlaku kompartemenisasi. Kompertamenisasi bersumber adanya pemisahan kekuasaan dan kewenangan penyidikan, penuntutan dan pemeriksaan serta pembuktian di pengadilan. Dengan perkataan lain terjadi deferensiasi fungsional di dalam Sistem Peradilan Pidana (SPP) Indonesia. Konsekuensi diferensiasi fungsional, maka kegiatan penyidikan tindak pidana umum sepenuhnya menjadi tugas dan tanggung jawab kepolisian, sedangkan kejaksaan di bidang penuntutannya. Hubungan fungsional kepolisian dan kejaksaan dalam kegiatan dalam rangka penyidikan guna penuntutan disebut pra penuntutan ${ }^{3}$. Hubungan tersebut terlaksana melalui media korespondensi (P1-P21), sehingga segala kegiatan penyidikan diarahkan dan diawasi secara horizontal oleh jaksa peneliti perkara melalui korespondensi berkas bukan secara langsung (on site).

Berdasarkan hubungan fungsional secara korespondensi tersebut berdampak pada bolakbaliknya berkas perkara antara penyidik dan jaksa peneliti perkara/penuntut umum. Dari aspek ekonomis, kenyataan demikian tidak efektif dan efesien, sedangkan dari aspek kepastian hukum bahwa kekuranglengkapan berkas perkara dan alat-alat bukti yang sah dari segi formil dan materil yang dikumpulkan penyidik akan melemahkan kegiatan pembuktian dan penuntutan perkara di pengadilan. Padahal jaksa akan memikul tanggung jawab yang besar dalam membuktikan dakwaannya ${ }^{4}$ dan meyakinkan hakim bahwa ada peristiwa pidana, ada pelakunya, melingkupi kesalahan, terdapat alat bukti dan barang bukti kemudian tiada alasan pemaaf dan pembenar, sehingga pelaku

Sutherweim, Dwi Windu Sejarah Kejaksaan, (Jakarta: Kejaksaan RI, 1991).

Tolib Effendi, Sistem Peradilan Pidana: Perbandingan Komponen dan Proses Sistem Peradilan Pidana di Beberapa Negara, (Yogyakarta: Pustaka Yustisia, 2013).

Pasal 139 KUHAP

4 Lihat Pasal 66 KUHAP. 
mesti dihukum untuk bertanggungjawab ${ }^{5}$. Dari segi keadilan, kekuranglengkapan tersebut dapat menimbulkan peradilan sesat yang menghukum orang tidak bersalah (miscariage of justice).

Padahal fungsionalisasi Sistem Peradilan Pidana Indonesia tidak boleh lepas dari spirit Sila kedua yakni "Kemanusiaan yang adil dan beradab" dan "Kelima yakni Keadilan Sosial Bagi Seluruh Rakyat Indonesia". Kemudian juga harus mengindahkan Pasal 28D ayat (1) UUD NRI Tahun 1945 yang menyatakan: "Setiap orang berhak atas pengakuan, jaminan, perlindungan, dan kepastian hukum yang adil serta perlakuan yang sama di hadapan hukum" dan harus pula memperhatikan asas keadilan hukum yang dimaksudkan di dalam Pasal 24 ayat (1) UUD NRI Tahun 1945 "Kekuasaan kehakiman merupakan kekuasaan yang merdeka untuk menyelenggarakan peradilan guna menegakkan hukum dan keadilan".

Bertolak dari hal tersebut, maka layak dipersoalkan: pertama, bagaimana dampak fatal lemahnya pengawasan horizontal jaksa kepada penyidik; dan argumentasi yuridis eksistensi lembaga pra penuntutan dalam KUHAP. Hal tersebut penting mengingat secara empiris saat ini bahwa mekanisme komunikasi antara kegiatan penyidikan dan penuntutan terhalang birokrasi kelembagaan dan egoisme sektoral. Hubungan kepolisian dengan kejaksaan menurut KUHAP sebenarnya tidak dapat dipisahkan dari segi peranan di dalam SPP, dengan kata lain equal atau sejajar. Nampak ada di dalam pandangan jaksa, bahwa polisi tidak memahami fungsi pengawasan horizontal yang dimiliki kejaksaan terhadap tugas dan wewenang penyidikan oleh kepolisian; Jaksa merasa dirinya paling bertanggungjawab di dalam pembuktian perkara di pengadilan (dominus litis). Sebaliknya dalam pandangan polisi bahwa polisi merasa menjadi "pesuruh" jaksa; dan jaksa kerap tidak mau memahami bagaimana beratnya tugas polisi mengumpulkan barang bukti dan alat bukti dengan mengolah tempat kejadian perkara (locus delicti) dan sebagainya. ${ }^{6}$ Apabila demikian, relevansi rumusan masalah tersebut di atas terhadap eksistensi lembaga Pra Penuntutan layak harus dijawab, mengingat memiliki fungsi penting yakni memperkuat landasaan yuridis, administratif dan faktual mengenai suatu kasus layak atau tidaknya dilimpahkan ke pengadilan.

\section{B. Metode Penelitian}

Penelitian dalam penyusunan artikel ini adalah menggunakan cara penelitian kualitatif, dengan tipe penelitian normatif dalam proses, prinsip, dan proseduryang digunakan. Kemudian sifat penelitian ini bersifat deskriptif analitis, dengan menggambarkan peraturan perundangundangan yang berlaku dan dikaitkan dengan asas hukum, teori hukum, norma hukum dalam praktik pelaksanaannya yang berkaitan dengan permasalahan yang akan diteliti dengan menguraikan dan menggambarkan mengenai fakta-fakta yang secara nyata terjadi sebagai pencerminan terhadap pelaksanaan dari asas hukum, teori hukum dan peraturan perundangundangan yang dikaitkan dengan teori-teori tersebut dan praktik pelaksanaannya.

Lihat Pasal 183 KUHAP.

6 Topo Santoso, Polisi dan Jaksa: Keterpaduan atau Pergulatan (Depok: Pusat Studi Pengadilan Pidana, 2000). hlm. 49. 
Adapun sumber data yang digunakan adalah data sekunder yang diperoleh dari dokumen resmi. Data tersebut meliputi bahan hukum primer, sekunder dan tersier. Bahan hukum primer antara lain: Undang-Undang Dasar 1945 amendemen ke-4; Undang-Undang Nomor 5 Tahun 1961 tentang Kejaksaan Rl; Undang-Undang Nomor 8 Tahun 1981 tentang Kitab Undang-Undang Hukum Acara Pidana; Undang-Undang Nomor 5 Tahun 1991 tentang Kejaksaan RI; Undang-Undang Nomor 30 Tahun 2002 tentang Komisi Pemberantasan Korupsi; Undang-Undang Nomor 2 Tahun 2002 tentang Kepolisian RI; Undang-Undang Nomor 16 Tahun 2004 tentang Kejaksaan Rl; Undang-Undang Nomor 48 Tahun 2009 jo. Undang-Undang Nomor 4 Tahun 2004 tentang Perubahan Undang-Undang Nomor 35 Tahun 1999 jo. Undang-Undang Nomor 14 Tahun 1970 tentang Pokok-Pokok Kekuasaan Kehakiman. Sedangkan bahan hukum sekunder meliputi: Buku-buku yang berkaitan Hukum dan Kriminologi; Jurnal mengenai Hukum dan Konstitusi; Hasil-hasil penelitian terdahulu yang dapat dijadikan bahan penjelasan terhadap bahan hukum primer. Bahan hukum tersier diperoleh dari Kamus Hukum dan Kamus Besar Bahasa Indonesia.

Selanjutnya teknik pengumpulan data dalam penulisan ini dilakukan melalui metode ini penelitian kepustakaan dengan mempelajari dan membaca buku-buku, jurnal, majalah, media cetak lainnya dan peraturan perundangundangan yang terkait serta bahan bacaan lainnya yang berhubungan dengan penulisan artikel ini, dalam rangka untuk mendapatkan landasan teoritis sebagai dasar. Kemudian analisis data dilakukan untuk dapat menjawab atau memecahkan permasalahan yang diangkat dalam makalah ini, penulis menggunakan analisis deskriptif kualitatif, yaitu setelah pengumpulan data dilakukan kemudian dianalisis, sehingga dapat ditarik suatu kesimpulan yang dapat dipertanggungjawabkan secara ilmiah. ${ }^{7}$

\section{Pembahasan}

\section{Dampak Fatal Lemahnya Pengawasan Horizontal Jaksa Kepada Penyidik.}

Kepastian hukum dan keadilan untuk sebagian orang tidak dapat disandingkan, karena satu sama lain memiliki tempat dan perspektif yang berbeda. Argumentasinya sederhana yakni jika kepastian hukum diutamakan, maka keadilan akan terabaikan, dan sebaliknya jika keadilan diutamakan maka kepastian hukum terabaikan. Akan tetapi, beberapa orang lain berpendapat bahwa hakim memeriksa dan memutus perkara seharusnya lebih condong kepada keadilan daripada kepastian hukum mengingat "irah-irah" di dalam putusan pengadilan sesuai Pasal 197 KUHAP bertuliskan "Demi keadilan berdasarkan Ketuhanan yang maha esa. ${ }^{8}$ Argumentasi tersebut juga bisa diterima. Namun ada pendapat yang moderat dan kompromistis bahwa kepastian hukum dan keadilan ibarat dua sisi koin mata uang (two faces of coin). Jadi ada keniscayaan untuk mewujudkan keduanya.

Kepastian hukum dan keadilan merupakan general expectation atau harapan semua orang, terlebih-lebih para pihak yang berperkara. Kepastian hukum akan mengacu kepada seperangkat aturan hukum, apakah hukum

\footnotetext{
Peter Mahmud Marzuki, Penelitian Hukum, (Jakarta: Kencana Prenada Media Group, 2005), hlm. 93-94.

8 Fachmi, Kepastian Hukum Mengenai Putusan Batal Demi Hukum Dalam Perkara Pidana (Jakarta: Raja Grafindo Persada, 2009), hlm. 335.
} 
pidana formil ataupun materil, sedangkan keadilan merujuk kepada hati nurani. Hati nurani itu ada di dalam perasaan religius penegak hukum, moralitas penegak hukum dan pemikiran reflektif penegak hukum. Hanya penegak hukum yang paripurna yang memiliki kemampuan memadukan kepastian hukum dan keadilan atau memilih di antara keduanya namun dapat diuji oleh pemikiran awam maupun pemikiran pakar atau orang kerap menyebut common sense.

Dunia penegakan hukum di Indonesia masih jauh dari dua kutub tersebut. Banyak kasus-kasus penegakan hukum justru dilakukan tidak cermat yang ditengarai sebagai dampak lemahnya fungsi pengawasan horizontal jaksa kepada penyidik dalam lembaga pra penuntutan. Kekurangcermatan tersebut menyebabkan ketidakpastian hukum, ketidakadilan serta melanggar hak asasi manusia. Misalnya dalam kasus Sumkuning di Yogyakarta, $1970^{9}$ dan Kasus Sengkon dan Karta yang monumental serta masih banyak kasus lain.

Dalam kasus Sengkon dan Karta, ${ }^{10}$ terungkap kejadian yang sebenarnya sebagai berikut: bahwa terjadi sebuah perampokan dan pembunuhan menimpa pasangan suami istri Sulaiman-Siti Haya di Desa Bojongsari, Bekasi tahun 1974. Polisi menciduk Sengkon dan Karta, dan menetapkan keduanya sebagai tersangka. Keduanya dituduh merampok dan membunuh pasangan Sulaiman-Siti Haya. Mereka merasa tidak bersalah karena melakukan tindak pidana tersebut, sehingga Sengkon dan Karta yang semula menolak menandatangani berita acara pemeriksaan, tetapilantaran taktahanmenerima siksaan polisi, keduanya lalu menyerah. Hakim Djurnetty Soetrisno lebih mempercayai cerita polisi ketimbang bantahan kedua terdakwa. Maka pada Oktober 1977, Sengkon divonis 12 tahun penjara, dan Karta 7 tahun. Putusan itu dikuatkan Pengadilan Tinggi Jawa Barat. Dalam dinginnya tembok penjara itulah mereka bertemu seorang penghuni penjara bernama Genul, keponakan Sengkon, yang lebih dulu dibui lantaran kasus pencurian. Di sinilah Genul membuka rahasia bahwa dialah sebenarnya pembunuh Sulaiman dan Siti. Akhirnya, pada Oktober 1980, Gunel dijatuhi hukuman 12 tahun penjara. Meski begitu, hal tersebut tak lantas membuat mereka bisa bebas. Sebab sebelumnya mereka tak mengajukan banding, sehingga vonis dinyatakan telah berkekuatan hukum tetap. Untungnya ada Albert Hasibuan, pengacara dan anggota dewan yang gigih memperjuangkan nasib mereka. Akhirnya, pada Januari 1981, Ketua Mahkamah Agung (MA) Oemar Seno Adji memerintahkan agar keduanya dibebaskan lewat jalur peninjauan kembali.

Berdasarkan kasus-kasus itu, lemahnya pengawasan penyidikan telah mendistorsi kepastian hukum, keadilan, perlindungan HAM tersangka menjadi terdakwa. Banyak kemungkinan penyebabnya, karena penegak hukum dengan kewenangan dan kekuasaan yang dimilikinya bisa berpotensi menyalahgunakan wewenang (abuse of power): ${ }^{11}$

1) Menggunakan jabatan dan/atau kekuasaannya untuk kepentingan pribadi dan/atau pihak lain;

\footnotetext{
9 Budiman Tanuredjo, Elegi Penegakan Hukum: Kisah Sumkuning, Prita Hingga Janda Pahlawan (Jakarta: BP. Kompas, 2010) hlm. 7-25.

10 Ibid. 33-48.

11 Pasal 4 Peraturan Jaksa Agung Nomor PER-067/A/JA/07/2007 tentang Kode Etik Jaksa.
} 
2) Merekayasa fakta-fakta hukum dalam penanganan perkara;

3) Menggunakan kapasitas dan otoritasnya untuk melakukan penekanan secara fisik dan/atau psikis;

4) Meminta dan/atau menerima hadiah dan/atau keuntungan serta menyuruh keluarganya meminta dan/atau menerima hadiah dan/atau keuntungan sehubungan dengan jabatannya;

5) Menangani perkara yang mempunyai kepentingan pribadi atau keluarga, mempunyai hubungan pekerjaan, partai atau finansial atau mempunyai nilai ekonomis secara langsung atau tidak langsung;

6) Bertindak diskriminatif dalam bentuk apapun;

7) Membentuk opini publik yang dapat merugikan kepentingan penegakan hukum;

8) Memberikan keterangan kepada publik terhadap hal-hal teknis perkara yang ditangani.

Berdasarkan kenyatan empiris itu, Lembaga Pra Penuntutan sebagai screening sebelum perkara dilimpahkan ke pengadilan mengalami marjinalisasi. Peran dan hubungan penyidik dengan penuntut umum memang terdapat kekurang-sepahaman terhadap masing-masing tanggung jawab hukum di dalam SPP, terutama kekurangsepahaman penyidik terhadap risiko penuntut umum jika tidak mampu membuktikan kesalahan perbuatan pelaku pidana di pengadilan, karena alat bukti yang diusung lemah dan tidak memenuhi aspek formil dan materil yang berimplikasi hakim membebaskan terdakwa.
Secara teknis peran penyidik itu hanya bertumpu pada aspek faktual peristiwa pidananya beserta upaya mengumpulkan alat buktinya (bewijsvoering), sedangkan jaksa itu memikirkan aspek yuridisnya (legal reasioning). ${ }^{12}$ Pada sisi ini kekurangsepahaman antarkeduanya akan rentan perbedaan persepsi mengenai konsepsi hukum mengenai "bukti permulaan yang cukup". Penyidik setelah mengumpulkan alat bukti dalam kasus yang sulit pengungkapannya, bisa saja keliru paradigma sehingga kondisi bukti permulaan yang cukup diasumsikan menjadi "alat bukti permulaan yang cukup". Padahal masing-masing alat bukti memiliki gradasi penghargaan yang tidak saja kuantitatif tetapi juga kualitatif (susficient evidence dan preponderance evidence) disebut probable cause. ${ }^{13}$ Selain itu dalam sistem pertanggungjawaban pidana menuntut adanya pelaku, harus adanya perbuatan, kesalahan dan ketentuan undang-undang yang melarang perbuatan tersebut serta ketiadaan alasan pemaaf dan pembenar. Menyadari hal ini, maka hubungan antara penyidik dengan jaksa peneliti perkara tidak bisa lagi secara korespondensi, besar kemungkinan perkara lemah pembuktiannya. Di masa yang akan datang, kritik masyarakat mengenai operasional sistem peradilan pidana semakin tajam, mesti diantisipasi agar tidak delay of justice.

Oleh sebab itu, harus ada solusi pertama, aspek regulasi dan kedua, aspek kelembagaan. Aspek regulasi bisa ditempuh dengan memperkuat pranata pra penuntutan dengan memperjelas mekanisme hubungan antara penyidik dan jaksa peneliti perkara/penuntut umum dalam kaitannya dengan hubungan

2 Hari Sasangka \& Lily Rosita Hukum Pembuktian Dalam Perkara Pidana (Bandung: Mandar Maju, 2003).

13 Eddy O.S. Hiariej, Teori dan Hukum Pembuktian, (Jakarta: Erlangga, 2012) hlm. 1-27. 
yang bersifat inter-personal aktif bukan korespondensi (surat-menyurat). Melalui cara ini yakni merinci pasal-pasal 110, 137, 139 KUHAP ke dalam ayat-ayat yang tegas memberikan mandatory rule kepada penyidik dan penuntut umum untuk mematuhi mekanisme tersebut di dalam RKUHAP. Kemudian memperluas obyek pranata hukum pra penuntut melalui regulasi sampai tahap awal peristiwa pidana yakni penyelidikan seperti keterlibatan dalam Olah Tempat Kejadian Perkara dan bewijsvoering serta seizure. Hal ini untuk menjamin keutuhan dan keabsahan barang bukti, alat bukti, kronologi kejadian perkara, dan tindakan hukum lain yang mesti dikonsultasikan kepada jaksa peneliti perkara secara dini. Penyangkalan dan pelanggaran regulasi pra penuntutan harus ditegakan dengan sanksi administratif, denda dan pidana penjara sebagai tanggung jawab moral dan profesionalisme penegak hukum.

Solusi kelembagaan juga penting dengan menghidupkan kembali komunikasi antarlembaga penegak hukum sebagaimana dahulu Mahkumjapol (MA, Kementerian Hukum dan HAM, Kejaksaan RI dan Kepolisian RI) dan Diljapol (Pengadilan, Kejaksaan Tinggi/ Negeri dan Kepolisian Daerah/Kepolisian Resort). Kekurangjelasan aturan mengenai pra penuntutan KUHAP dengan memperluas peran jaksa peneliti perkara juga dapat ditempuh melalui koordinasi kelembagaan agar tidak menimbulan perasaan saling curiga dan mengurangi egoisme sektoral. Dari forum dan koordinasi dalam pertemuan itu dapat menghasilkan Surat Edaran Bersama tentang Revitalisasi Pranata Pra Penuntutan Perkara Pidana dan issue seputar keberhasilan penyelidikan, penyidikan dan penuntutan perkara pidana.

\section{Argumentasi Yuridis Eksistensi Lembaga Pra Penuntutan Dalam KUHAP}

Dalam mencermati keberadaan Lembaga Pra Penuntutan dalam SPP Indonesia ada beberapa alasan yang kuat untuk mempertahankan dan merevitalisasinya termasuk di dalam RKUHAP yang akan datang. Argumentasinya berasal dari aspek normatif-doktrinal dan normatif-empiris.

\section{a. Kajian Normatif-Doktrinal Eksistensi Lembaga Pra Penuntutan}

Interelasi antara penyidik dan penuntut umum dimulai dengan preposisi menurut Undang-Undang Nomor 8 Tahun 1981 tentang KUHAP. Pasal 1 angka 2 KUHAP menyatakan bahwa, Penyidikan adalah"Serangkaian tindakan untuk mencari dan mengumpulkan buktibukti dan dengan bukti-bukti mana penyidik membuat terang suatu tindak pidana yang terjadi dan guna menemukan tersangka sebagai pelaku yang akan dipertanggungjawabkan atas terjadinya tindak pidana itu."14

Sedangkan Penuntutan diatur dalam Pasal 137 KUHAP, yang menyatakan bahwa, Penuntutan adalah "Tindakan penuntut umum untuk melimpahkan perkara ke pengadilan negeri yang berwenang dalam hal dan menurut cara yang diatur dalam dalam KUHAP, dengan permintaan supaya perkara tersebut diperiksa oleh hakim di sidang pengadilan." ${ }^{15}$

Dari perumusan yang telah dibakukan dalam KUHAP tentang Penyidikan dan Penuntutan tersebut, memberikan pengertian bahwa

14 Andi Hamzah dan Irdan Dahlan, Surat Dakwaan, (Bandung: PT. Alumni, 1987), hlm. 78.

15 Ibid. 
perkara pidana adalah hasil penyidikan yang dilakukan oleh penyidik atas suatu tindak pidana. Hal ini terlihat jelas dalam ketentuan Pasal 110 ayat (1) KUHAP, yang menentukan bahwa dalam hal penyidik telah selesai melakukan penyidikan, penyidik "wajib segera" menyerahkan berkas perkara itu kepada penuntut umum. ${ }^{16}$

Kemudian perkara hasil penyidikan itu oleh penuntut umum dilimpahkan kepada pengadilan negeri yang berwenang guna diperiksa dan diputus di sidang pengadilan. Hubungan antara penyidikan dan penuntutan akan lebih jelas lagi bila kita kaitkan dengan ketentuan Pasal 139 KUHAP, yang menentukan bahwa setelah penuntut umum menerima atau menerima kembali hasil penyidikan yang lengkap dari penyidik, ia segera menentukan apakah berkas perkara itu sudah memenuhi persyaratan untuk dapat atau tidak dilimpahkan ke pengadilan. ${ }^{17}$

Selanjutnya menurut ketentuan Pasal 140 ayat (1) KUHAP, menyatakan bahwa dalam hal penuntut umum berpendapat bahwa dari hasil penyidikan dapat dilakukan penuntutan. Penuntut umum dalam "waktu secepatnya membuat surat dakwaan." ${ }^{18}$

Pelimpahan perkara ke pengadilan sesuai dengan ketentuan Pasal 143 ayat (4) KUHAP, dilakukan oleh penuntut umum dengan surat pelimpahan perkara dalam mana terlampir surat dakwaan. ${ }^{19}$

Hubungan normatif antara penyidik dan penuntut umum sebagaimana diuraikan pasal-pasal tersebut di atas dikenal di dalam praktik adalah Pra Penuntutan. Kegiatan pra penuntutan yakni mekanisme "korespondensi" antara penyidik dan penuntut umum senantiasa mengalami dinamika. Bahkan dinamika tersebut kerap tidak berkutat atau berhubungan dengan kasus yang ditangani saja, dipengaruhi oleh persoalan psikologis dalam penanganan suatu kasus.

Dalam konteks hubungan penyidik dan penuntut umum berdasarkan penelitian terdahulu bahwa mengenai persepsi antara polisi dan jaksa tentang Lembaga Pra Penuntutan: ${ }^{20}$ Pertama, menurut Polisi bahwa Jaksa sering memberikan petunjuk yang tidak jelas. Jaksa memberi petunjuk agar mengubah soal $\mathrm{X}, \mathrm{Y}$, $Z$ tetapi sesudah itu diubah, malah meminta diperbaiki lagi, agar menjadi soal A, B, C dan seterusnya. Sebaliknya menurut Jaksa bahwa Polisi sering tidak melaksanakan petunjuk dari Jaksa dengan benar, sehingga harus berkali-kali bolak-balik membuang waktu.

Kedua, menurut Polisi bahwa Jaksa sering tidak mengerti penyidikan pidana umum jauh lebih sulit daripada pidana khusus. Sebaliknya menurut Jaksa bahwa Polisi tidak mengerti bahwa penyidikan pidana khusus jauh lebih sulit dari pidana umum dan membutuhkan pengetahuan yang luas.

Ketiga, menurut Polisi bahwa Polisi seharusnya menjadi penyidik utama karena polisilah yang bertanggungjawab terhadap hasil penyidikan. Sebaliknya menurut Jaksa bahwa Jaksa harus ikut serta dalam penyidikan karena Jaksa menduduki posisi sentral dan yang paling bertanggungjawab di pengadilan.

Ibid.

Ibid.

Ibid.

Ibid.

20 Luhut M.P. Pangaribuan Lay Judge dan Hakim Adhoc: Suatu Studi Teoritis Mengenai Sistem Peradilan Pidana Indonesia (Jakarta: FH UI, 2009), hlm. 159-160. Lihat juga Topo Santoso Op.Cit hlm. 103. 
Keempat, menurut Polisi bahwa Jaksa sering mengubah isi pasal-pasal tuduhan dari polisi, sehingga melemahkan hasil pemeriksaan polisi di pengadilan, padahal polisi sudah bekerja keras untuk ini. Sebaliknya menurut Jaksa bahwa Polisi sering memberikan dasar hukum pemeriksaan yang kurang kuat, sehingga Jaksa lemah di pengadilan. Untuk ini, Jaksa harus mengubah lagi, karena Jaksa yang paling bertanggungjawab.

Kelima, menurut Polisi bahwa tidak ada yang mengawasi berkas perkara yang tidak dilanjutkan Jaksa ke pengadilan, sedangkan Polisi dapat di pra peradilan. Sebaliknya menurut Jaksa bahwa tidak ada yang dapat mengawasi Polisi jika berkas perkara yang diminta Jaksa untuk diperbaikinya tidak dikembalikan ke Jaksa lagi, jumlahnya ribuan.

Keenam, menurut Polisi bahwa jika kemampuan Polisi memang kurang, yang perlu diperbaiki personel polisinya, bukan dengan mengubah sistem yang ada. Sebaliknya, menurut Jaksa bahwa kekurangmampuan Polisi harus ditopang dengan sistem yang memberikan proses beracara secara cepat dan tepat.

Berdasarkan polarisasi hubungan antara polisi dan jaksa tentang penilaian masingmasing, bukan menjadikan suatu alasan untuk menghapuskan lembaga pra penuntutan di dalam RKUHAP yang akan datang. Argumentasinya hasil penyidikan adalah dasar bagi penyusunan surat dakwaan, kebenaran bahwa hasil penyidikan ini adalah dasar dari pada penyusunan surat dakwaan ${ }^{21}$ yang menentukan laik atau tidaknya perkara dilimpahkan ke pengadilan. Jangan sampai perkara tidak cukup bukti disidangkan di pengadilan sehingga menghukum orang tidak bersalah. Selama ini jaksa menerima berkas dari polisi tanpa terlibat langsung dalam penyidikan, misalnya olah TKP, dan intrograsi calon tersangka sekalipun sight and within hearing, tidak seperti penasihat hukum.

Terdapat berbagai alasan logis mengenai keniscayaan keterlibatan langsung Jaksa di dalam mekanisme Pra Penuntutan pada tahap penyidikan. Pendapat para jurist antara lain: A. Karim Nasution mengutip Idema menyatakan: ".........jaksa haruslah menguasai seluruh pemeriksaan perkara, dan sejak dari penuntutan sampai akhir ialah pemimpinnya yang mempertimbangkan segala sesuatu, atau yang menggerakkan tangan-tangan petugas kepolisian represif". ${ }^{22}$ Dari pendapat guru besar dan praktisi hukum (mantan jaksa) ini jelas bahwa Jaksa adalah dominus litis di dalam perkara pidana, dimana ia dapat menggerakan polisi untuk mengikuti petunjuknya agar keberhasilan pembuktian dan penuntutan yang menjadi tugas dan tanggungjawabnya terwujud. Namun demikian, A. Karim Nasution ${ }^{23}$ menyatakan:

\footnotetext{
" ... jaksa sebenarnya tidak boleh mengemukakan tuduhan semaunya, tetapi terikat dari hasil-hasil pemeriksaan pendahuluan (penyidikan) ... dalam menyusun surat dakwaan untuk tidak memulai terlebih dahulu kualifikasi, baru diikuti dengan perumusannya, tapi hendaknya langsung saja kepada tindak pidana yang didakwakan dirumuskan sesuai dengan isi pemeriksaan pendahuluan."
}

Pandangan itu berpangkal adanya keterikatan erat antara hasil penyidikan-penyidik

\footnotetext{
21 Andi Hamzah Op.Cit., hlm. 78.

22 A. Karim Nasution Masalah Surat Tuduhan Dalam Proses Pidana (Jakarta: Percetakan Negara RI, 1972), hlm. 48.

$23 \quad$ Ibid hlm. 43 dan 113.
} 
berdasarkan pemeriksaan pendahuluan dengan upaya jaksa menyusun surat dakwaan (acte van verwijzing), maka secara psikologis dan hukum, jaksa sangat bertanggungjawab terhadap pembuktian dan penuntutan perkara pidana. Ketidakberhasilan pembuktian perkara pidana berdasarkan surat dakwaan yang mengacu kepada hasil penyidikan pemeriksaan pendahuluan, kini ada 2 (dua) konsekuensi logis yang harus diterima jaksa, yakni pertama, cemooh dari korban, masyarakat pencari keadilan, pemerhati hukum, mass media; kedua, menghadapi proses eksaminasi atasan (internal) atau kemungkinan terburuk demosi.

Sehubungan tanggung jawab jaksa yang berat di dalam proses pembuktian dan penuntutan perkara pidana di pengadilan, guru besar hukum pidana dan mantan jaksa Andi Hamzah ${ }^{24}$ menyatakan: "... untuk menyusun suatu surat dakwaan yang cukup memadai haruslah dengan mempelajari hasi pemeriksaan pendahuluan ... hasil pemeriksaan pendahuluan (penyidikan) merupakan dasar bagi penuntut umum untuk menyusun surat dakwaan." Bahkan di dalam RKUHAP yang akan datang, beliau mengusulkan keterlibatan jaksa secara langsung di dalam proses penyidikan agar kualitas pemeriksaan pemeriksaan pendahuluan bisa diketahui, dipahami dan dihayati yang berguna dalam mempertahankan alat bukti dan barang bukti serta peritiwa pidana secara utuh. Pada hematnya, hal ini logis karena jika dianalogi bahwa seorang saksi saja tidak boleh testimoni de auditu (mendengar dari orang lain) di dalam KUHAP, maka dengan jaksa mempercayai hasil penyidikan polisi hanya menerima informasi sepihak bisa bias. Peran jaksa di dalam proses penyidikan demikian penting untuk mengetahui langsung dari penyidik on site agar mencegah alur perkara ada intervensi kepentingan yang "non yudisial" dari pihak manapun yang mesti difasilitasi di dalam KUHAP.

Gambaran utuh mengenai informasi substansial surat dakwan penting, tak kurang M.Yahya Harahap menyatakan bahwa "surat dakwaan adalah surat atau akte yang memuat rumusan tindak pidana yang didakwakan kepada terdakwa yang disimpulkan dan ditarik dari hasil pemeriksaan penyidikan." 25 Jadi rumusan surat dakwaan harus benar-benar sejalan dan seiring dengan hasil penyidikan. Apabila hakim menjumpai rumusan surat dakwaan yang menyimpang dari hasil pemeriksaan penyidikan, hakim dapat menyatakan bahwa surat dakwaan tidak dapat diterima, atas alasan ini surat dakwaan kabur atau obscuur libel. Karena rumusan surat dakwaan tidak senyawa (pen. koheren ${ }^{26}$ ) dan tidak menegaskan secara jelas uraian tindak pidana yang diperoleh dari pemeriksaan penyidikan dengan apa yang diuraikan dalam surat dakwaan. Berpangkal pada uraian di atas, jelaslah bahwa penyusunan surat dakwaan yang baik akan sangat bergantung pada hasil penyidikan yang baik pula.

Kegiatan penyidikan memang tidak bisa dilepaskan dari peranan jaksa sebagai pengendali perkara pidana (dominus litis). Posisi dominus litis jaksa memang sering para sarjana hukum juga memperdebatkan dengan berbagai latar belakang kepentingan dan

24 Andi Hamzah Hukum Acara Pidana Indonesia (Jakarta: Sinar Grafika, 2008), hlm. 36 dan 82.

25 M. Yahya Harahap Pembahasan Permasalahan dan Penerapan KUHAP: Penyidikan dan Penuntutan (Jakarta: Sinar Grafika, 2006), hlm. 415.

26 Peter Mahmud Marzuki, Pengantar Ilmu Hukum, (Jakarta: Kencana Prenada Media Group, 2013), hlm. 89 Ada beberapa pendekatan dalam menilai suatu proporsi hukum yakni korespondensi dan koherensi. 
pengalaman serta pengetahuannya. Namun demikian check and balances of power lembaga penyidikan oleh kepolisian yang dominan akan berhadap-hadapan dengan perlindungan hak asasi manusia tersangka yang berlaku di negara hukum modern seperti Indonesia harus dihormati dan diaplikasikan oleh para penegak hukum. Dengan perkataan lain, keberadaan lembaga pra penuntutan yang diperankan jaksa sebagai penyeimbang atau barrier terhadap kemungkinan kepolisian menyimpangi kewenangannya.

Argumentasi hukumnya adalah di dalam doktrin Hukum Administrasi Negara ${ }^{27}$ sebagai hukum yang menaungi seluruh hukum penyelenggaraan pemerintahan termasuk administrasi peradilan (administration of court and administration of justice) menggariskan bahwa "geen bevougheid is zonder verant woordelijkheid atau there is no a authority without responsibility) atau tiada kewenangan tanpa pertanggungjawaban". ${ }^{28}$

Bertalian dengan itu, maka penyimpangan dan/atau penyelewengan KUHAP dalam tingkat penyidikan dan pra penuntutan yang memiliki risiko fatal jika tersangka diputus bebas, semestinya RKUHAP memberikan ancaman sanksi pidana bagi penegak hukum yang melakukan mal praktik dan/atau melawan hukum. Mengapa ketentuan mengenai sanksi harus dicantumkan di dalam UU (RKUHAP) karena, perbuatan a quo dapat dikaitkan erat dengan unsur melawan hukum yang diartikan oleh Wirjono Prodjodikoro sebagai "merugikan kepentingan subjektif orang lain, bertentangan dengan ketentuan hukum objektif dan tanpa hak"29

Peranan jaksa di dalam pemeriksaan pendahuluan atau Pra Penuntutan juga penting menjalankan fungsi pengawasan horizontal yang berlaku efektif di negara maju. Hal ini bukannya tanpa dasar ilmiah bahwa Volker F. Krey menggambarkan hubungan penyidik dan penuntut umum di Jerman saja bahwa:

"Penuntut umum memberikan petunjuk (instructions) pada penyidik dalam pemeriksaan perkara pidana. Sebab penuntut umum, sebagaimana di Perancis adalah merupakan guardian of the law. Polisi akan terlalu berkuasa bila polisi di satu sisi melakukan pengamanan dan di sisi lain sekaligus juga yang prosecuting suatu kasus. Kekuasaan polisi yang terlalu kuat ini berbahaya untuk hak-hak konstitusional masyarakat. Penyidikan yang dilakukan penyidik atas perkara pidana berat pada akhirnya penuntut umum yang memutuskan dengan kedudukan sebagai ruler over the criminal investigations apakah akan mendakwa atau tidak perkara pidana di pengadilan. Keadaan ini justru akan membantu kepolisian terhadap kemungkinan adanya resistance against certain criminal

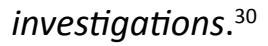

Jerman adalah negara dengan sistem hukum kontinental seperti Perancis, Belanda dan Indonesia.

27 Ridwan HR Hukum Administrasi Negara (Jakarta: Rajawali Press, 2006). Lihat pendapat Van Vollen Hoeven bahwa induk dari hukum acara adalah hukum administrasi.

28 Nur Basuki Minarno Penyalahgunaan Wewenang dan Tindak Pidana Korupsi Dalam Pengelolaan Keuangan Daerah, (Palangkaraya: Laksbang, 2009), hlm. 75-76. Prinsip tersebut serupa dengan asas legalitas di dalam Hukum Pidana.

29 Wirjono Prodjodikoro Tindak-Tindak Pidana Tertentu (Jakarta: Raja Grafindo Persada, 2005), hlm. 50.

30 Volker F. Krey Characteristic Features of German Criminal Proceedings, an Alternative to the Criminal Procedure Law of the United States dalam Luhut op.cit hlm. 163. Lihat juga "Loyola of Los Angeles International and Comparative Law Journal", August, (1994):4. 
Di Perancis the senior public prosecutors are responsible for watching over police investigations and must be kept informed by the police of the procedure carried out. ${ }^{31}$ Dalam pengawasan itu, ada beberapa kemungkinan yang dilakukan oleh jaksa yang dalam praktik di Indonesia disebut jaksa peneliti (the screening prosecutor), yaitu:

Pertama, may accept the charge recommended by the police, atau Kedua, raise or reduce that charge, atau Ketiga, request that the police obtain further evidence (which may require releasing the arrestee at this point and then rearresting him when and if that evidence is obtained) atau Keempat, decide against prosecution if the arrestee will participate in a diversion program, atau Kelima, simply decide against prosecution without condition. ${ }^{32}$

Selain itu, bisa penyidikan polisi itu ditolak atas dasar "interests of justice" tetapi penolakan berdasarkan "interests of justice" sering menjadi kontroversial. Penolakan berdasarkan alasan ini kurang dari 10\% dari keseluruhan penyidikan yang ditolak jaksa. ${ }^{33}$ Berdasarkan pengamatan penulis, di Indonesia jarang penuntut umum menolak hasil penyidikan dengan alasan menjaga hubungan baik, kendati proses bewijsvoering tersebut masih menimbulkan pertanyaan teoritis dan yuridis untuk mengujinya (jika ada tahap pre eliminary seperti di AS), ${ }^{34}$ karena jaksa di Indonesia tidak terlibat langsung dalam proses bewjisvoering secara fisik.

\section{Kajian Normatif-Empiris Eksistensi Lembaga Pra Penuntutan}

Salah satu batu uji eksistensi lembaga pra penuntutan yakni upaya penahanan penyidik terhadap tersangka. Sebagaimana diketahui mengenai sikap penyidik, penuntut umum dan hakim terkadang berbeda mengenai perlu atau tidaknya tersangka untuk ditahan. Sementara itu, tindakan penahanan terdapat mekanisme permohonan izin oleh penyidik kepada penuntut umum dan hakim. Penahanan ini dapat dilakukan jika seseorang diduga keras melakukan tindak pidana (vide Pasal 1 butir 14 dan Pasal 17 ayat (1) KUHAP). Jadi dalam pandangan awam, sikap subyektif penegak hukum dalam menahan tersangka sulit diukur (free discreation), misalnya tiba-tiba seorang saksi menjadi tersangka.

Dalam praktik, seseorang ditahan ketika permohonan izin diajukan tanpa dihadirkan penyidik ke pengadilan. Demikian pula ketika permohonan perpanjangan kepada penuntut umum tidak disertakan tahanannya dan alasan-asalan yang cukup substansial. Padahal penting untuk melihat urgensinya dan tugas ini masih dalam kerangka Pra Penuntutan. Alasan penahanan sesuai Pasal 21 KUHAP sangat normatif. Oleh karenanya peran jaksa dan hakim dalam lembaga pra penuntutan dapat menilai perlu tidaknya seseorang ditahan agar ada fungsi kontrol. Apabila seseorang terduga keras pelaku tindak pidana dalam kondisi

31 Charles Elliot and Catherine Vernon, France Lega System (Edinburg Gate: Longman Pearson Education, 2000), hlm. 145 dalam Luhut op.cit. hlm. 163.

32 Yale Kamisar Cs., Modern Criminal Procedure, Cases, Commnets, and Question, American Book Casesbook Series, (St. Paul Minn: West Group, 1999), hlm. 21-22 dalam Luhut Ibid hlm. 164.

33 Ibid.

34 Hor, Michael "Burden of Proof Siangpore Law Journal" Singapore, 2008. Lihat juga Hohfeld, Wesley Newcomb, Fundamental Legal Conceptions as Applied in Judicial Reasoning With an Introduction by Nigel Simmonds, edited by David Campbell and Philip Thomas (Dartmouth, 2001). 
sakit, berusia tua atau cacat fisik, maka upaya penahanan menjadi tidak diperlukan. Selama ini kiprah lembaga pra penuntutan menjadi tidak maksimal karena komunikasi antara penyidik dan penuntut umum hanya korespondensi berkas.

Keadaan itu menyebabkan ketidakseimbangan antara kepentingan hukum (recht belangen) tersangka yang inferior ketimbang penyidik yang superior. Penyidik adalah juga manusia bisa keliru atau memiliki kepentingan atau pertimbangan lain yang salah. Kekeliruan dapat mengakibatkan ketidakpastian hukum, ketidakadilan serta pelanggaran hak asasi manusia bagi tersangka, namun juga menyebabkan instabilitas dan keresahan dalam masyarakat, seperti peristiwa tahanan mati di dalam rutan polisi memicu penyerangan kantor polisi atau adanya perlakuan berbeda antara seorang tersangka A tidak ditahan tetapi tersangka B ditahan dalam kasus yang sama. Kekacauan akan menghambat pembangunan nasional. Jadi supremasi hukum merupakan pra syarat stabilitas pembangunan nasional. Teori Kenneth S. Carlston bahwa:

"kelompok hancur atau cerai berai atau
punah disebabkan karena hukum gagal
dalam melaksanakan tugasnya. Tugas hukum
haruslahdijalankansebabtugasinimerupakan
kondisi yang tidak dapat digantikan dalam
mencapai tujuan yang sebenarnya dari setiap
kelompok. Hukum tidak merupakan tujuan
itu sendiri, melainkan merupakan instrumen
yang tidak dapat digantikan untuk mencapai
tujuan biologis tertinggi yang nyata dari
aktivitas manusia."

Bukankah keberadaan hukum dalam masyarakat untuk menjaga harmoni kehidupan bersama. Penegakan hukum yang tidak mengindahkan nilai-nilai yang hidup dalam masyarakat akan mengalami distrust dan resistensi masyarakat, sehingga bisa saja masyarakat mengambil jalannya sendiri misalnya sikap selfredress (main hakim sendiri). Untuk itulah lembaga pra penuntutan sebagai pranata hukum ada harus maksimal, menurut Huntington Cairns bahwa:

"Ilmu pengetahuan hukum sebagai suatu sociotechnique mampu membuat dan menerapkan peraturan-peraturan hukum yang diperlukan guna mencapai tujuantujuan sosial yang diharapkan, penggunaan hukum sebagai a tool of social engineering meliputi penggunaan peraturan-peraturan yang dirumuskan oleh lembaga-lembaga pembuat peraturan yang menimbulkan suatu akibat tertentu pada tingkah laku pemegang peran, yaitu untuk mewujudkan tujuantujuan tertentu yang dikehendaki." ${ }^{\prime 36}$

Tuntutan pentingnya koordinasi secara"fisik" antara penyidik dan penuntut umum dalam wadah lembaga pra penuntutan diperlihatkan dengan contoh perbedaan perlakuan penyidik atas penahanan para tersangka dalam kasus yang sama. Masih banyak tindakan hukum penyidik yang memerlukan pengawasan melalui lembaga pra penuntutan misalnya mencegah upaya penyidik menyita barang yang tidak terkait dengan tindak pidana (vide Pasal 39 KUHAP).

Dalam konteks tindakan penahanan seharusnya dimaknai memiliki alasan yuridis normatif dan sosiologis. Segi yuridis diatur di dalam Pasal 21 KUHAP, sedangkan sosiologis merupakan interpretasi penyidik, penuntut umum dan hakim yang tidak kaku (contra legem). 
Dua aspek tersebut harus dipertimbangkan karena menurut Hulsman (ahli hukum pidana Belanda), penahanan itu merupakan lembaga paling penting di antara beberapa lembaga penggunaan paksaan dalam hukum acara pidana. ${ }^{37}$ Manfaat penahanan menurut Jordan C.J.: ${ }^{38}$

Any detention which is reasonably necessary until a magistrate can be obtained is, of course, lawful, but detention which extends beyond this cannot be justified under the common law or statutory power. Thus it has been held that if in the course of an arrest which is otherwise for a lawful purpose, the arresting constable takes the arrested person to some place to which it would not be reasonable and proper to take him in the course of bringing him before a magistrate, for the purpose of searching him there, the detention in that place and the search are unauthorised and therefore actionable...

Menurut pandangan ini bahwa setiap penahanan harus dianggap cukup berasalan sampai izin hakim secara sah dapat diperoleh, namun penahanan dilakukan tanpa izin ini tidak dapat dibenarkan berdasarkan kekuasaan undang-undang (civil law) dan sistem hukum common law. Oleh karena itu pelaksanaan "penahanan dilakukan hanya jika alasan penahanan tujuan yang legal".

Ketetapan penahanan seseorang yang mana tidak berdasar dan bertujuan membawanya sebelum ke pengadilan seperti untuk keperluan penyelidikan saja di sana, penahanan di tempat itu dan penyelidikan tersebut adalah tidak sah dan karena itu tidak perlu ditindaklanjuti.
Di sini peran jaksa dan hakim dalam mengawasi penyidik sangat penting dalam fungsi lembaga pra penuntutan untuk "menjustifikasi" atau menolak setiap permohonan penahanan calon tersangka melalui pertimbangan yang tepat. Argumentasinya bahwa setiap tindakan penahanan adalah merampas kemerdekaan seseorang dan penyidik kepolisian bisa saja dihadapkan kenyataan sebagaimana diilustrasikan Jordan C.J.: ${ }^{39}$

If a person has been arrested, and is in the process of being brought before a magistrate, questioning within limits is regarded as proper in New South Wales ... but a police officer has no more authority to restrain the liberty of a suspected person for the purpose, not of taking him before a magistrate, but of interrogating him, than he has of restraining the liberty of a person who may be supposed to be capable of supplying information as a witness.

Di New South Wales (Australia), jika seseorang telah ditangkap, dan di dalam prosesnya sebelum dibawa ke hakim, untuk mempertanyakan alasannya dalam batas-batas yang dianggap tepat, sedangkan polisi tidak memiliki kewenangan yang lebih untuk menahan kebebasan seseorang yang diduga melakukan tindak pidana sebelum membawanya kepada seorang hakim, kecuali menginterogasi dia, daripada menahan kebebasan yang ia miliki kemungkinan lebih baik mempertimbangkan kemampuannya memasok informasi sebagai saksi. Jadi ketiadaan bukti tidak memaksa penyidik untuk menahan seseorang cukup

L. Hc. Hulsman, Sistem Peradilan Pidana Dalam Perspektif Perbandingan Hukum, Saduran oleh Soedjono D. (Jakarta: Rajawali, 1984), hlm. 79.

38 D Brown, D Farrier, D Neal and D. Weisbrot, Criminal Laws: Materials and Commentary on Criminal Law and Process of New South Wales (Sydney: Federation Press, 1990) at 7.

39 AIJA "Conference papers of Det Insp Lupo Prins; and Tasmanian DPP Damian Bugg", at 13. Lihat juga L. Prins, Video Recording of Police Interviews (Tasmanian Police, October 1989). 
sebagai saksi saja, apalagi menganiaya serta dilanggar hak asasinya.

Di Indonesia, eksistensi lembaga pra penuntutan telah memberikan kewenangan jaksa peneliti perkara untuk melakukan pengawasan horizontal kepada penyidik, hanya belum memberi kesempatan kepada penuntut umum untuk terlibat langsung sejak olah TKP dan tindakan hukum lain. Kesempatan itu sangat siginifikan bagi pengemban hukum mengingat dalam sistem perundang-undangan pidana di Indonesia secara sistematis mengatur bahwa setiap orang disangka, ditangkap, ditahan, dituntut atau dihadapkan di depan pengadilan wajib dianggap tidak bersalah sampai adanya putusan pengadilan yang menyatakan kesalahannya dan berkekuatan hukum tetap. Hal tersebut sesuai dengan bunyi Pasal 8 ayat (1) Undang-Undang Nomor 48 Tahun 2009 tentang Kekuasaan Kehakiman bahwa:

\footnotetext{
"Setiap orang yang disangka, ditangkap, ditahan, dituntut, atau dihadapkan di depan pengadilan wajib dianggap tidak bersalah sebelum ada putusan pengadilan yang menyatakan kesalahannya dan telah memperoleh kekuatan hukum tetap."
}

Ketentuan ini dikenal dengan asas praduga tidak bersalah yang disebut asas presumption of innocence, yang menghendaki agar setiap orang yang menjalani proses perkara pidana tetap dianggap tidak bersalah sampai ada putusan pengadilan yang berkuatan hukum tetap yang menyatakan kesalahannya.

Hakim dalam sistem peradilan pidana Indonesia diberikan kewenangan oleh undangundang untuk memutuskan seseorang bersalah atau tidak bersalah melalui proses penegakan hukum dan keadilan di pengadilan. Hal ini berarti kesalahan seseorang hanya dapat ditentukan dalam suatu putusan hakim yang berkekuatan hukum tetap disebut inkracht van gewijsde, oleh karena itu seseorang harus dianggap tidak bersalah atau benar dalam arti tidak pernah melakukan kesalahan, sehingga berhak mendapatkan perlindungan hukum selama dalam proses peradilan menurut Hukum Acara Pidana.

Asas praduga tidak bersalah merupakan salah satu bentuk perlindungan hukum sebagai asas hukum acara pidana yang berlaku dalam setiap proses perkara pidana di pengadilan sebagaimana diatur di dalam penjelasan butir 3c Undang-Undang Nomor 8 Tahun 1981 tentang Kitab Undang-Undang Hukum Acara Pidana. ${ }^{40} \mathrm{Hal}$ itu mesti diacu dan dilandasi pada setiap tindakan penangkapan, penahanan, penuntutan dalam sistem peradilan pidana di Indonesia.

Acuan demikian, sangat diperhatikan sehingga diatur di dalam Pasal 32 UndangUndang Nomor 48 Tahun 2009 tentang Kekuasaan Kehakiman yang menentukan bahwa selain pengadilan, badan-badan lain yang fungsinya berkaitan dengan kekuasaan kehakiman adalah penyelidikan, penyidikan dan penuntutan, pelaksanaan putusan, pemberian jasa hukum, dan penyelesaian sengketa di luar pengadilan.

Dalam proses perkara pidana, asas praduga tidak bersalah diartikan sebagai ketentuan yang menganggap seseorang yang menjalani proses pemidanaan, tetap tidak bersalah sehingga harus dihormati hak-haknya sebagai warga Negara sampai ada putusan pengadilan negeri yang menyatakan kesalahannya. Penerapan

40 Abdul Wahab Daud KUHAP dan UUPG (Jakarta: Pusbakum, 2002), hlm. 99. Lihat Juga Yahya M. Harahap Op.Cit, hlm. 65. 
asas praduga tidak bersalah di dalam KUHAP merupakan suatu upaya untuk melindungi hak-hak tersangka selama proses penyelidikan, penyidikan, penuntutan, pemeriksaan di pengadilan sampai kepada pemidanaan yang berasal dari putusan hakim yang berkekuatan hukum tetap yang menyatakan kesalahannya.

Asas praduga tidak bersalah yang dikenal di dalam KUHAP berasal dari Het Herziene Inland Reglement atau HIR. Asas itu dikenal secara universal karena merupakan sebagian dari hidup kejiwaan manusia. Asas merupakan produk filsafat hukum dimana menurut mazhab natural atau hukum alam, ${ }^{41}$ memberi posisi bahwa asas merupakan spirit dari hukum ${ }^{42}$ atau esprit de la lois karena dalam setiap asas merefleksikan cita hukum manusia yang hendak diraihnya. Berbeda dengan aturan hukum yang bersifat preskriptif atau memerintahkan sebagai kenyataan sebagaimana seharusnya terjadi atau das sollen, maka asas merupakan harapan bahwa setiap orang disangka, ditangkap, ditahan, dituntut atau dihadapkan di depan pengadilan wajib dianggap tidak bersalah sampai adanya putusan pengadilan yang menyatakan kesalahannya dan berkekuatan hukum tetap, namun dalam kenyataannya, asas hukum tersebut tidak selalu diterapkan. Penyidik, penuntut umum dan hakim harus memahami hal ini.

Dalam upaya untuk melindungi hak-hak asasi manusia dari kemungkinan ancaman dan pelanggaran oleh penguasa (baca: penegak hukum), Deklarasi Universal Hak Asasi Manusia atau DUHAM PBB juga menekankan tentang pentingnya kelembagaan peradilan yang bebas dan merdeka.
Lembaga peradilan yang bebas itu diharapkan mampu melakukan pemeriksaan dan penilaian yang obyektif atas kasus-kasus sengketa hak yang dihadapkan kepadanya. Dan secara khusus hak-hak tersangka ini terdapat dalam Pasal 9 - 15 Konvensi Hak Sipil dan Politik (Sipol) yang menjadi prinsip-prinsip pelaksanaan Fair Trial (peradilan yang adil dan tidak memihak). ${ }^{43}$

Peradilan yang tidak memihak berkaitan erat dengan hukum materil-substansif maupun hukum acara atau KUHAP. Itu sebabnya, pelanggaran yang menyebabkan peradilan menjadi memihak, bukan hanya dikualifikasi sebagai pelanggaran prosedural, tetapi merupakan tindakan yang bersifat melawan hukum.

Dalam konteks penilaian atas tindakan penahanan dan peran lembaga pra penuntutan, penyidik, penuntut umum dan hakim harus menyadari bahwa hak atas fair trial sebagai sebuah norma dalam hukum HAM internasional, dirancang untuk melindungi individu dari pembatasan yang tidak sah dan sewenangwenang atau perampasan atas hak-hak dasar dan kebebasan-kebebasan lainnya.

Dalam pemenuhan hak ini perlu diperhatikan bahwa sistem peradilan yang dimaksud tidak hanya melihat dan menilai, bagaimana proses pemeriksaan atas suatu kasus di muka persidangan saja, tapi juga harus dilihat bagaimana proses awal yang mendahului suatu peradilan atau pra persidangan dan juga pasca persidangan. Dengan demikian, juga harus dilihat bagaimana proses penangkapan, penahanan atau bentuk-bentuk upaya paksa lainnya terhadap seorang Tersangka atau saksi,

41 Herman Bakir, Filsafat Hukum dan Desain Sejarah dan Kearsitekturan, (Jakarta: Raja Grafindo Persada, 2006), hlm. 90.

42 Montesquie Semangat Hukum Terjemahan Wisnu Basuki (Jakarta: Nusa Media, 2006).

43 Konvenan Internasional Tentang Hak Sipil Dan Politik, Dalam Lembar Fakta HAM, (Jakarta: Komnas HAM, 2005). 
serta proses pemeriksaan dan pembuatan berita acara pemeriksaan di tingkat penyidikan. ${ }^{44}$

Menurut Pasal 14 ayat (2) Konvensi Sipol "Setiap orang yang didakwa melakukan satu tindak pidana punya hak untuk dianggap tidak bersalah sampai dibuktikan bersalah menurut hukum." Dalam kaitan dengan asas praduga tidak bersalah, harus diperhatikan: ${ }^{45}$

a) Asas praduga tak bersalah menempatkan beban pembuktian selama persidangan pidana kepada penuntut umum. Tuntutan pidana selayaknya dibuktikan dengan kepastian yang mendalam atas fakta-fakta yang benar atau di atas alasan yang masuk akal, setiap standar pembuktian menghasilkan perlindungan bagi asas praduga tak bersalah di dalam hukum nasional.

b) Pihak yang berwajib harus menjaga asas praduga tak bersalah. Ketentuan-ketentuan ini berlaku untuk para hakim yang memimpin persidangan dan untuk petugas lain yang berurusan dengan kasus tersebut. Tersangka belum dapat dinyatakan sebagai terhukum selama sidang masih berlangsung. Pihak berwenang, termasuk jaksa penuntut umum, dapat menginformasikan kepada publik mengenai penyelidikan tindak pidana atau tuntutan-tuntutannya tetapi tidak diperbolehkan menyatakan seolah-olah terdakwa sudah bersalah.

c) Anggapan hukum atas fakta atau peraturanperaturan dapat berlaku dalam suatu kasus hanya jika tidak dibantah, memperbolehkan terdakwa membuktikan ketidakbersalahannya. d) Dalam pelaksanaan asas praduga tak bersalah, negara tidak diperkenankan untuk menagih biaya pembelaan bagi seseorang yang telah dinyatakan tak bersalah.

e) Dalam pelaksanaan asas praduga tak bersalah, negara tidak diperkenankan untuk menagih biaya penuntutan baik semua atau sebagian kepada seseorang yang dinyatakan tak bersalah melakukan tindak pidana.

Asas ini sangat penting karena proses penegakan hukum di satu sisi harus dihindari dari kemungkinan kesewenang-wenangan dan karena itu harus menghormati asas praduga tak bersalah. Di sisi lain, tidak menegakkan hukum dengan "menipu" masyarakat sama seriusnya dengan pelanggaran hukum itu sendiri. Dengan demikian perlu adanya saling mengawasi di antara para penegak hukum.

Sebagaimana Pasal 66 KUHAP, tersangka atau terdakwa tidak dibebani pembuktian, sehingga paksaan penyidik kepadanya untuk mengaku saja melanggar asas non-self incrimination itu sendiriadalah suatu hal yang tidak diperbolehkan dilakukan dalam suatu proses peradilan pidana. Hal itu dapat berupa tindakan atau pernyataan yang diambil atau berasal dari seseorang sehingga dengan tindakan atau pernyataan itu dirinya menjadi in a crime. Larangan berasal dari pemahaman bahwa merupakan beban negara untuk menuduh dan membawa seseorang ke pengadilan, serta membuktikan kesalahannya itu. Seseorang yang menjadi tertuduh tidak dapat dipaksa membantu kewajiban negara itu. Karena ini adalah hukum, tidak ada relevansinya dengan mengatakan, misalnya, tidak taat hukum. ${ }^{46}$

\footnotetext{
44 http://Kuhap.Or.Id/Data/Wp-Content/Uploads/2013/09/Prinsip-Prinsip-Fair-Trial.Pdf.

45 Ibid.

46 Rolando V. del Carmen Criminal Procedure: Law and Practice, Eighth Edition (Wadsworth 10 Davis Drive Belmont, CA 94002-3098 USA, 2010), hlm. 18.
} 
Keberadaan asas nonself incrimination tersebut di atas merupakan penyeimbang asas res judicate pro veritate habetur, bahwa putusan hakim sebagai hukum harus dianggap sebagai suatu kebenaran. Semua putusan hakim mengingat para pihak yang bersengketa yakni jaksa dan terdakwa beserta penasihat hukumnya, sejak diucapkan dalam sidang terbuka untuk umum dan mempunyai kekuatan berlaku apabila putusan tersebut sudah berkuatan hukum tetap. Lembaga pra penuntutan penting mempedomani asas-asas hukum, karena asas merupakan: ${ }^{47}$

"A fundamental truth; a comprehensive law or doctrine, from which others are derived, or on which others are founded; a general truth; an elementary proposition; a maxim; an axiom; a postulate; The collectivity of moral or ethical standards or judgments; $A$ basic truth, law, or assumption; A settled rule of action; a governing law of conduct; The collectivity of moral or ethical standards or judgments."3

Terkait itu, Frank Schmalleger menegaskan mengenai cakupan Hukum Acara Pidana juga terikat asas hukum dan aturan hukum sebagai berikut:

Procedural law is another kind of statutory law. It is a body of rules which regulate the processing of an offender by the criminal justice system. Procedural law, for example, specifies in most jurisdictions that the testimony of one party to certain "victimless crimes" cannot be used as the sole evidence against the other party. General rules of evidence, search and seizure, procedures to be followed in arrest, and other specified processes by which the justice system operates are contained in procedural law. ${ }^{48}$

Oleh karena dalam konteks penyidikan dan pra penuntutan harus mempedomani hukum acara, maka RKUHAP yang akan datang harus mengakomodasi perluasan kewenangan Pra Penuntutan Jaksa Peneliti Perkara dalam pemeriksaan pendahuluan tingkat penyidikan. Perkuatan lembaga pra penuntutan dalam KUHAP merupakan keniscayaan karena hukum acara pidana merupakan jenis lain dari hukum perundang-undangan. Ini adalah Kitab aturan yang mengatur proses seorang tersangka dan terdakwa dalam sistem peradilan pidana. Hukum acara, misalnya, menentukan di sebagian besar wilayah hukum bahwa kesaksian satu pihak tertentu "kejahatan tanpa korban" tidak dapat digunakan sebagai bukti tunggal terhadap pihak lain. Ketentuan umum mengenai pembuktian, penyelidikan, penyidikan dan penyitaan, prosedur yang harus diikuti dalam penangkapan, dan proses tertentu lainnya dimana sistem peradilan beroperasi berdasarkan hukum acara. Tanpa prosedur KUHAP akan terjadi kesewenang-wenangan bertindak.

\section{Penutup}

Berdasarkan hal itu, disimpulkan bahwa fungsionalisasi lembaga pra penuntutan harus mengalami perluasan peran jaksa peneliti perkara dalam tahap pemeriksaan pendahuluan pada tingkat penyidikan mengingat: Pertama 
dampak lemahnya pengawasan antar penegak hukum dalam lembaga pra penuntutan akan menciptakan ketidakpastian hukum, delay of justice, dan pelanggaran hak asasi manusia serta penegakan hukum yang melawan hukum (abuse of power). Kedua, perkuatan eksistensi dan perluasan peran jaksa peneliti perkara dalam lembaga pra penuntutan berdasarkan KUHAP akan mewujudkan kesepahaman antara penyidik dengan jaksa peneliti perkara/ penuntut umum, guna memperkecil risiko gagalnya penuntutan perkara pidana akibat tidak mampu membuktikan kesalahan perbuatan pelaku pidana di pengadilan, kemudian mencegah dipaksakannya pelimpahan perkara oleh penyidik kepada penuntut umum untuk disidangkan.

Sehubungan hal tersebut diperlukan penguatan lembaga pra penuntutan secara tegas dan jelas di dalam RKUHAP sebagai pranata hukum yang mampu melindungi legal principles, legal norms dan legal rule dalam penyidikan perkara pidana. Kemudian, seiring dengan perluasan obyek pra peradilan oleh Mahkamah Konstitusi, agar seimbang maka keberadaan lembaga pra penuntutan mesti mengalami perluasan peran jaksa peneliti perkara sampai ke tingkat penyelidikan sehingga dapat diberi ruang dan wewenang yang cukup untuk terlibat langsung dalam mengawasi bewijsvoering pada tingkat penyelidikan dan penyidikan sebagai dominus litis (penguasa perkara). Agar lembaga pra penuntutan dengan penerapan hukum acara pidana dapat menjamin kepastian hukum, keadilan, melindungi Hak Asasi Manusia dengan kinerja pembuktian yang akurat, akuntabilitas, transparansi dan terhindar dari (zero) putusan hakim berupa lepas dari segala tuntutan, bebas murni, dan putusan bebas tidak murni (Pasal 244 KUHAP dan yurisprudensi MA Reg
Nomor 275/k/Pid/1983). Oleh karena itu, setiap tindakan penyidik dan penuntut umum dalam pra penuntutan yang melawan hukum, sepantasnya dilekatkan dengan sanksi-sanksi (administratif, denda, dan pidana) sesuai prinsip tiada kewenangan tanpa pertanggungjawaban.

\section{DAFTAR PUSTAKA}

\section{Buku}

Bakir, Herman, Filsafat Hukum dan Desain Sejarah dan Kearsitekturan, (Jakarta: Raja Grafindo Persada, 2006)

Brown, D., D Farrier, D Neal and D. Weisbrot, Criminal Laws: Materials and Commentary on Criminal Law and Process of New South Wales (Sydney: Federation Press, 1990)

Carmen, Rolando V., del Criminal Procedure: Law and Practice, Eighth Edition (USA: Wadsworth 10 Davis Drive Belmont, CA 94002-3098, 2010)

Daud, Abdul Wahab, KUHAP Dan UUPG, (Jakarta: Pusbakum, 2002)

Effendi, Tolib, Sistem Peradilan Pidana: Perbandingan Komponen dan Proses Sistem Peradilan Pidana di Beberapa Negara (Yogyakarta: Pustaka Yustisia, 2013)

Elliot, Charles and Catherine Vernon, France Lega System (Edinburg Gate: Longman Pearson Education, 2000)

Fachmi, Kepastian Hukum Mengenai Putusan Batal Demi Hukum Dalam Perkara Pidana, (Jakarta: Raja Grafindo Persada, 2009)

Hamzah, Andi, dan Irdan Dahlan, Surat Dakwaan, (Bandung: PT. Alumni, 1987)

Hamzah, Andi, Hukum Acara Pidana Indonesia (Jakarta: Sinar Grafika, 2008)

Harahap, Yahya M. Pembahasan KUHAP dan Permasalahannya: Penyidikan dan Penuntutan (Jakarta: Sinar Grafika, 2002)

Hiariej, Eddy O.S., Teori dan Hukum Pembuktian. (Jakarta: Erlangga, 2012)

Hohfeld, Wesley Newcomb, Fundamental Legal Conceptions as Applied in Judicial Reasoning With an Introduction by Nigel Simmonds, edited by David Campbell and Philip Thomas (Dartmouth, 2001)

Hulsman, L. Hc., Sistem Peradilan Pidana Dalam Perspektif Perbandingan Hukum, Saduran oleh Soedjono D. (Jakarta: Rajawali, 1984) 
Kamisar, Yale Cs., Modern Criminal Procedure, Cases, Commnets, and Question, American Book Casesbook Series, (St. Paul Minn: West Group, 1999)

Krey, Volker F., Characteristic Features of German Criminal Proceedings, an Alternative to the Criminal Procedure Law of the United States

Marzuki, Peter Mahmud, Penelitian Hukum, (Jakarta: Kencana Prenada Media Group, 2005)

Marzuki, Peter Mahmud, Pengantar IImu Hukum, (Jakarta: Kencana Prenada Media Group, 2013)

Minarno, Nur Basuki, Penyalahgunaan Wewenang dan Tindak Pidana Korupsi Dalam Pengelolaan Keuangan Daerah, (Palangkaraya: Laksbang, 2009)

Montesquie, Semangat Hukum, Terjemahan Wisnu Basuki (Jakarta: Nusa Media, 2006)

Nasution, A. Karim, Masalah Surat Tuduhan Dalam Proses Pidana (Jakarta: Percetakan Negara RI, 1972)

Pangaribuan, Luhut M.P. Lay Judge dan Hakim Adhoc: Suatu Studi Teoritis Mengenai Sistem Peradilan Pidana Indonesia, (Jakarta: UI Press, 2009)

Prodjodikoro, Wirjono, Tindak-Tindak Pidana Tertentu (Jakarta: Raja Grafindo Persada, 2005)

Ridwan, HR, Hukum Administrasi Negara (Jakarta: Rajawali Press, 2006)

Santoso, Topo, Polisi dan Jaksa: Keterpaduan atau Pergulatan (Depok: Pusat Studi Pengadilan Pidana, 2000)

Sasangka, Hari dan Lily Rosita, Hukum Pembuktian Dalam Perkara Pidana, (Bandung: Mandar Maju, 2003)

Schmalleger, Frank Criminal Justice A Brief Introduction (Regents/Prentice Hall, Englewood Cliffs, New Jersey 07632)

Soemitro, Ronny Hanitijo, Masalah-masalah Sosiologi Hukum, (Bandung: Sinar Baru, Bandung, 1984)

Sutherweim, Dwi Windu Sejarah Kejaksaan, (Jakarta: Kejaksaan RI, 1991)

Tanuredjo, Budiman, Elegi Penegakan Hukum: Kisah Sumkuning, Prita Hingga Janda Pahlawan, (Jakarta: BP. Kompas, 2010)

\section{Makalah/Artikel/Prosiding/Hasil Penelitian}

AIJA Conference papers of Det Insp Lupo Prins; and Tasmanian DPP (Damian Bugg, at 13)

Hor, Michael "Burden of Proof Siangpore Law Journal" Singapore, 2008.
Jordan "Legal Principles, Legal Values and Legal Norms: are they the same or different?" Academicus - International Scientific Journal European School of Law and Governance, (Prishtina, Kosovo Universum University, Prishtina, Kosovo)

Konvenan Internasional Tentang Hak Sipil Dan Politik, Dalam Lembar Fakta HAM, (Jakarta: Komnas HAM, 2005)

Krey, Volker, "Characteristic Features of German Criminal Proceedings: An Alternative to the Criminal Procedure Law of the United States?" 21 Loy. L.A. Int'I \& Comp. L.J. 591-605 (1999)

Krey, Volker, "Deutsches Strafrecht, Allgemeiner Teil - Lehrbuch in Deutsch und Englisch", Vol. 1: Grundlagen / Basics. (Kohlhammer, Stuttgart 2002)

Krey, Volker, Volker, "Deutsches Strafrecht, Allgemeiner Teil - Lehrbuch in Deutsch und Englisch", Vol. 2: Tatbestand des vorsätzlichen Begehungsdelikts / Legal Elements of the Intentional Offence Committed by Action. (Kohlhammer, Stuttgart 2003)

Po- Jen Yap "Four Models of Equality" Loyola of Los Angeles International and Comparative Law Journal,: 1 (2005)

Prins, L., "Video Recording of Police Interviews" (Tasmanian Police, October 1989)

\section{Internet}

http://Kuhap.Or.Id/Data/Wp-Content/ Uploads/2013/09/Prinsip-Prinsip-Fair-Trial.Pdf

\section{Peraturan}

Undang-Undang Dasar 1945 amendemen ke-4 Undang-Undang Nomor 8 Tahun 1981 tentang Kitab Undang-Undang Hukum Acara Pidana

Undang-Undang Nomor 30 Tahun 2002 tentang Komisi Pemberantasan Korupsi

Undang-Undang Nomor 2 Tahun 2002 tentang Kepolisian RI

Undang-Undang Nomor 16 Tahun 2004 tentang Kejaksaan RI

Undang-Undang Nomor 48 Tahun 2009 jo. UndangUndang 4 Tahun 2004 tentang Perubahan Undang-Undang No. 35 Tahun 1999 jo. UndangUndang No. 14 Tahun 1970 tentang Pokok-Pokok Kekuasaan Kehakiman

Resolusi PBB No. 2200 A (XXI) mengesahkan International Covenant on Civil 
and Political Rights (Kovenan Internasional tentang Hak-Hak Sipil dan Politik), dan Optional Protocol to the International Covenant on Civil and Political Rights (Opsional Protokol Kovenan Internasional tentang Hak Sipil dan Politik) tanggal 16 Desember 1966 dan berlaku pada tanggal 23 Maret 1976

Peraturan Pemerintah Nomor 27 Tahun 1983 tentang Pedoman Pelaksanaan KUHAP
Peraturan Jaksa Agung Republik Indonesia Nomor: PER-067/A/JA/07/2007 tentang Kode Etik Jaksa

Putusan MA Yurisprudensi MA Reg Nomor 275/k/ Pid/1983 tentang Kasasi Terhadap Putusan Bebas

Putusan No 21/PUU-XII/2014 tentang Perluasan Obyek Pra Peradilan 
"Halaman ini dikosongkan" 